\title{
A comparative study of conventional premedication (pethidine, promethazine, and atropine) and neuroleptanalgesia (droperidol and phenoperidine) for peroral endoscopy
}

\author{
W. D. REED, B. E. HOPKINS, R. A. JOSKE, ${ }^{1}$ AND B. H. LAURENCE \\ From the Department of Medicine, University of Western Australia, and The Royal Perth Hospital
}

SUMMARY A double blind comparison of conventional premedication (pethidine, promethazine, and atropine) and neuroleptanalgesia (droperidol and phenoperidine) failed to demonstrate any difference in either the comfort of the patient or ease of instrumentation in 70 upper gastrointestinal tract endoscopies.

Further trials are needed before conventional premedication is abandoned.

It is generally agreed that premedication is necessary for endoscopy using topical anaesthesia. A variety of drug combinations have been used. One of the two standard texts recommends either pethidine or amylobarbitone sodium (Bockus and LennardJones, 1963) and the other papaveretum and scopolamine (Jones and Gummer, 1968). The addition of promathezine has been reported to produce more satisfactory preparation than pethidine and an anticholinergic alone (Findlay, 1962). More recently diazepam alone (Rider, Puletti, and Desai, 1970) and in combination with pethidine (Ticktin and Trujillo, 1965; 1968; Mayes, Kehoe, Friedman, and Belher, 1970) has been tried. Neuroleptanalgesia with phenoperidine and fentanyl (Ferrari and Stephen, 1967) or phenoperidine and droperidol (Smeeton, 1966) has more recently been employed successfully. Few controlled trials, however, have been published. This study compares premedication with pethidine $(100 \mathrm{mg})$, promethazine $(25 \mathrm{mg})$, and atropine $(0.6 \mathrm{mg})$ with the neuroleptanalgesic combination of phenoperidine $(2 \mathrm{mg})$ and droperidol (5 mg).

\section{Methods and Materials}

In this double blind study patients were randomly allocated using random number tables to one of the two premedication groups.

Both premedications were administered intra-

'Please request reprints from R. A. Joske, Department of Medicine, Victoria Square, Perth, Western Australia, 6000.

Received for publication 30 June 1971. muscularly one hour before endoscopy. Topical anaesthesia with $4 \mathrm{ml}$ of $2 \%$ amethocaine hydrochloride was used in all cases. All examinations were performed by one of two endoscopists (R.A.J. or B.H.L.). Instruments used were a Hirchowitz fiberscope, an Olympus GFB fibergastroscope, and a Lopresti FO fiberoesophagoscope.

Of 106 consecutive examinations performed in the institution over 26 months, 70 examinations in 67 patients are analysed. Reasons for exclusion are shown in Table I. There is no reason to suspect that

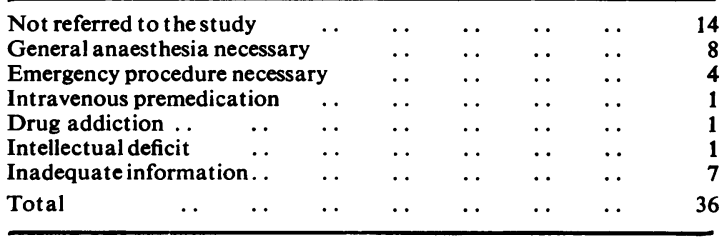

Table I Reasons for exclusion from study

those patients not referred were in any way different from the studied sample. There were 45 males and 22 females ranging in age from 24 to 87 years, with a mean age in each sex of 55 years. Of the 70 endoscopies, there were 64 gastroscopies, five patients had combined oesophagoscopy and gastroscopy, and one oesophagoscopy alone.

The endoscopist completed a standard assessment immediately after the examination and was asked to grade the patient's attitude and degree of coopera- 
tion as well as the physical ease of the procedure (Table II).

Patients completed their questionnaire within 24 hours of the procedure and were asked (Table III) about anxiety, memory for the procedure, degree of discomfort suffered, and whether or not they would agree to the procedure being repeated.

\section{Results}

Table II shows the results of the endoscopists' evaluation of patient preparation and Table III the patients' responses. Statistical analysis of these results was accomplished using the $\chi^{2}$ method with Yates correction applied where necessary. There was no significant difference between conventional premedication and neuroleptanalgesia in either the suitability of the patients for endoscopy or response of the patient to the procedure. Patient responses appear consistent in that of the 59 who would agree to a repeat examination, 48 felt no pain.

\begin{tabular}{lcc}
\hline & $\begin{array}{l}\text { Pethidine } \\
\text { Promethazine } \\
\text { Atropine }\end{array}$ & $\begin{array}{l}\text { Phenoperidine } \\
\text { Droperidol }\end{array}$ \\
\hline Patient's Attitude & & \\
Too heavily sedated & 0 & 1 \\
Ideally cooperative & 25 & 26 \\
Anxious & 7 & 9 \\
Uncooperative & 1 & 1 \\
Total & 33 & 37 \\
Intubation & & \\
Easy & 25 & \\
Mild difficulty & 5 & 21 \\
Difficult but completed & 2 & 14 \\
Abandoned & 1 & 2 \\
Total & 33 & 37 \\
\hline
\end{tabular}

Table II Results of endoscopists' assessments

\begin{tabular}{lcc}
\hline Response & $\begin{array}{l}\text { Conventional } \\
\text { Premedication }\end{array}$ & $\begin{array}{l}\text { Neurolept- } \\
\text { analgesia }\end{array}$ \\
\hline Frightened & 4 & 5 \\
Anxious but composed & 10 & 18 \\
At ease & 19 & 14 \\
Remembered fully & 26 & 32 \\
Hazy memories & 7 & 5 \\
Painful & 8 & 13 \\
Not painful & 25 & 24 \\
Would agree to repeat & 28 & 31 \\
Refused repeat & 5 & 6 \\
\hline
\end{tabular}

Table III Patients' responses to endoscopy

Although anxiety and discomfort were slightly prominent in the neuroleptanalgesic group in both the endoscopists' and patients' assessments, the differences were not significant. The procedure was abandoned on only one patient in each test group and was difficult in only four patients $(6 \%)$, two being from each group. The endoscopists found mild difficulty, however, in a greater proportion $(38 \%)$ of patients receiving the neuroleptanalgesic combination than in those who received the pethidinepromethazine-atropine combination $(15 \%)$. Only one patient receiving neuroleptanalgesia was too heavily sedated, and the majority $(83 \%)$ fully remembered the procedure.

\section{Discussion}

This study was begun following the introduction of neuroleptanalgesia, a state produced by the combination of a neuroleptic butyrophenone derivative and a potent analgesic as a premedication for various endoscopic procedures on conscious patients (Farb and Tornetta, 1965; Smeeton, 1966; Ferrari and Stephen, 1967). Advantages claimed included depression of sensitive local reflexes, amnesia for the procedure, and minimal side effects.

The present study failed to show any significant difference between neuroleptanalgesia and conventional premedication from both the endoscopist's and the patient's viewpoint. Sufficient reflex abolition, sedation, and muscular relaxation was obtained to enable intubation with ease or only mild difficulty in most cases in both groups (conventional premedication group $91 \%$, neuroleptanalgesia group $95 \%$ ). No adverse cardiovascular or respiratory side effects occurred in either group, and abnormal psychomotor sensations, which have been reported with neuroleptanalgesia, were not encountered.

Although no significant difference emerged in this small series there is a greater incidence of patient anxiety and difficulty of intubation in the neuroleptanalgesia group. A larger sample may indeed demonstrate definite inferiority of neuroleptanalgesia in these important respects when compared with pethidine, promethazine, and atropine.

The presence of atropine in the conventional combination did not affect the ease and adequacy of examination, although oneendoscopist commented consistently on the presence of decreased gastric motility when atropine had been given and not when the alternative drugs were used. It would seem that atropine could be introduced at the discretion of the endoscopist depending on his wish to reduce secretions or gut motility.

Local prices make the neuroleptanalgesic combination considerably more expensive than conventional premedication.

Until neuroleptanalgesics are demonstrated to have definite advantages, conventional premedication with pethidine, promethazine, and atropine is preferred and is economically more acceptable. 
We wish to thank all those consultants who referred cases for study and the nursing staff and registrars for diligent collection of data.

\section{References}

Bockus, H. L. (1963). Gastroenterology, 2nd ed., p. 321. Saunders, Philadelphia.

Farb, S., and Tornetta, F. J. (1965). Topical endoscopic anesthesia with two new adjuncts. Eye, Ear, Nose, Thr. Monthly, 44 (10), (Abstr.), 56-58.

Ferrari, H. A., and Stephen, C. R. (1967). Bronchoscopy and esophagoscopy under neuroleptanalgesia with droperidol-fentanyl. J. thorac. cardiovasc. Surg., 54, 143-149.

Findlay, C. W., Jr. (1962). The value of promethazine hydrochloride in preparing patients for peroral endoscopy. Amer. Rev, resp. Dis., 86, 272-274.

Jones, F. A., Gummer, J. W. P., and Lennard-Jones, J. E. (1968). Clinical Gastroenterology, 2nd ed., p. 821. Blackwell, Oxford.

Mayes, G. R., Kehoe, E. L., Friedman, E., and Belher, J. (1970). Pre-endoscopic medication: parenteral diazepam used adjunctively. Gastroint. Endosc., 26, 187-193.

Rider, J. A., Puletti, E. J., and Desai, D. C. (1970). The use of diazepam in esophagoscopy and gastroscopy. (Abstr.), Gastroenterology, 58, 1075.

Smeeton, W. M. (1966). Experiences with neuroleptanalgesia. Neuroleptanalgesia in anaesthetic practice. In Proceedings of the First Australian Symposium on Neuroleptanalgesia, p. 49.

Ticktin, H. E., and Trujillo, N. P. (1965). Evaluationeof diazepam for pre-endoscopy medication. Amer. J. dig. Dis., 10, 979-984.

Ticktin, H. E., and Trujillo, N. P. (1968). Further experience with diazepam for pre-endoscopic medication. Gastroint. Endosc., 15, 91-92.

\section{The August 1971 Issue}

\section{THE AUGUST 1971 ISSUE CONTAINS THE FOLLOWING PAPERS}

Immunofluorescent localization of secretin in the canine duodenum JULIA M. POLAK, S. BLOOM, I. COULLING, AND A. G. E. PEARSE

An evaluation of ${ }^{113}$ indium DTPA chelate in the measurement of gastric emptying by scintiscanning R. C. HEADING, P. TOTHILL, A. J. LAIDLAW, AND D. J. C. SHEARMAN

The effect of diazepam on human gastric secretion D. BIRNBAUM, F. KARMELI, AND MAKONNEN TEFERA

Effect of food on serum gastrin evaluated by radioimmunoassay M. G. KORMAN, C. SOVENY, AND J. HANSKY

Alimentary transit and supersensitivity after vagotomy in the rat L. V. GUTIERREZ, N. KOCAK, AND ALAN G. COX

Electrical stimulation and insulin tests used with bilateral selective vagotomy $D$. HOLLANDERS

The role of bile salts in diarrhoea of patients with ulcerative colitis T. A. MIETTINEN

Argentaffin cells in ulcerative colitis J. M. SKINNER, R. WHITEHEAD, AND JUAN PIRIS
Gastric ulcer and gastritis M. W. L. GEAR, S. C. TRUELOVE, AND R. WHITEHEAD

ABO blood groups, secretor status, salivary protein, and serum and salivary immunoglobulin concentrations J. G. WAISSBLUTH AND M. J. S. LANGMAN

Determinants of salivary response to mechanical stimulation ANDRE L. BLUM AND GABRIEL M. MAKHLOUF

Polyethylene glycol 4000 as a continuously administered non-absorbable faecal marker for metabolic balance studies in human subjects R. WILKINSON

\section{Technique}

A modification of charcoal adsorption immunoassay of gastric intrinsic factor H. A. GHAZI AND VALERIE ANNERSON

Progress report Intestinal schistosomiasis H. A. K. HOWLAND

Progress report The intestinal brush border $\mathbf{R}$. HOLMES

Notes and activities

Copies are still available and may be obtained from the PUBLISHING MANAGER, BRITISH MEDICAL ASSOCIATION, TAVISTOCK SQUARE, LONDON, WC1H 9JD, price $87 \frac{1}{2} \mathrm{p}$ 